\title{
Finske frivillige i krigen 1864
}

af ROLF JOHANSSON

I krigen 1864 viste de nordiske broderfolk deres solidaritet med Danmark. Det gjaldt også finnerne, selv om deres land dengang hørte til Rusland. I alt 11 finner gjorde krigen med på dansk side. Presse- og kulturattaché Rolf Johansson, Finlands ambassade i København, fortæller her om det lille kontingent fra »storfyrstendømmet Finland«.

I et hjørne af parken ved Kastellet i København er der et lille, velholdt monument for de nordiske frivillige, der deltog i de danske krige $\mathrm{i}$ årene $1848-50$ og 1864. Hvert år arrangerer Kastellets garnison en mindehøjtidelighed, hvortil der også inviteres repræsentanter for den svenske, norske og finske ambassade.

Sådan som Bernhard Estlander, nevø til en af de finske frivillige Rudolf Estlander, udtrykte det, gav Sverige og Norge tilsammen i $1864 \mathrm{~s}^{\dagger}$. rumefræenden Danmark et antal på godt og vel et halvt tusinde frivillige og noget lignende i penge, klæder, forbindsartikler og i tilgift dertil "en masse krigeriske eder og forbandelser på værtshuse og caféer ", og han fortsatte: "Antallet af vore [de finske] frivillige var endnu mere beskedent ...«. ${ }^{1}$ Finnernes antal var 11.

Elleve mand i en krig er en dråbe $i$ havet, uanset hvor godt de gør deres pligt. Men det har sin interesse at belyse, hvorfor disse elleve var beredt til at ofre liv og lemmer for Danmark i krigen 1864; ingen finner deltog nemlig i Treårskrigen. Og hvem var disse frivillige? Hvordan var f.eks. deres oplevelser undervejs til krigsskuepladsen, af selve felttoget, af militærsygehuse og krigsfangenskab. Og havde deres kamp nogen betydning?

\section{I fremmed krigstjeneste}

Efter Napoleonskrigene havde Kongeriget Danmark mistet Norge til Sverige, men havde beholdt Slesvig og Holsten og erhvervet Lauenburg mod en del af Pommern. Sverige var på sin side i 1809 blevet tvunget til at afstå Finland til Rusland. Finland var blevet et storfyrstendømme $\mathrm{i}$ det russiske rige og havde fået lov til at beholde de 
gamle svenske love. Finland kunne således udvikle sin autonomi med landdag og senat, egen administration og omfattende okonomisk selvstændighed. I 1860erne var der ca. 1,7 mill. indbyggere i Finland, hvoraf $80 \%$ boede på landet eller ernærede sig ved jordbrug. De største byer var Helsingfors, Åbo, Viborg og Tammerfors. Til sammenligning var der 1,6 mill. indbyggere i Kongeriget Danmark (2,6 mill. i helstaten), mens der boede 163.000 i København mod kun 30.000 i Helsingfors.

Russisk udenrigspolitik i Norden gik ud på at neutralisere Sverige. I Finland førte dette bl.a. til, at hovedstaden blev flyttet fra vestkysten mod øst, altså fra Åbo til Helsingfors, og at man lempeligt forsøgte at begunstige det finske sprog på bekostning af det svenske. Danmark blev ikke anset for en fjende. Rusland havde bl.a. tvunget Preussen til at trække sig ud af Treårskrigen, hvilket fik krigslykken til at svinge fra de oprørske slesvig-holstenere til fordel for danskerne. Men inden krigen 1864 var de dansk-russiske relationer blevet betydeligt afsvalede.

Under Krimkrigen havde Danmark trods sin formelle neutralitet de facto lettet den engelske og franske orlogsflådes sejlads gennem Øresund til Østersøen. Desuden opfattede Rusland det forhold, at visse økonomiske koncessioner - såsom jernbanebyggeriet - gik til repræsentanter for vestmagterne som en potentiel trussel. For det tredje, så fandtes der i det enevældige kejserdømme en ideologisk modvilje mod "folkestyrets Danmark". Derfor havde Rusland nærmet sig Preussen - men også som tak for, at Preussen havde støttet zarregimet i kampen mod det polske oprør 1863.

Danmark havde søgt støtte hos sin gamle arvefjende Sverige. Men til trods for sympatien for "skandinavismen « bl.a. hos kongerne Oscar I og Karl XV, så var de svenske regeringer ikke villige til at stille militært op på Danmarks side. Det stod klart allerede i 1850erne og endnu mere i 1864. For Rusland udgjorde en skandinavisk union mellem Sverige-Norge og Danmark en selvklar trussel, så storfyrstendømmet Finland var officielt bundet ved kejserens politik. Desuden var den datidige finske politiske elite stort set tilfreds med situationen. Der herskede fred og ro i landet, økonomien blomstrede og finske militærfolk og tjenestemænd blev lokket af en lukrativ fremtid i det russiske imperies tjeneste. Finske militære enheder havde loyalt deltaget i Krimkrigen og det polske oprør på russisk side. ${ }^{2}$ 


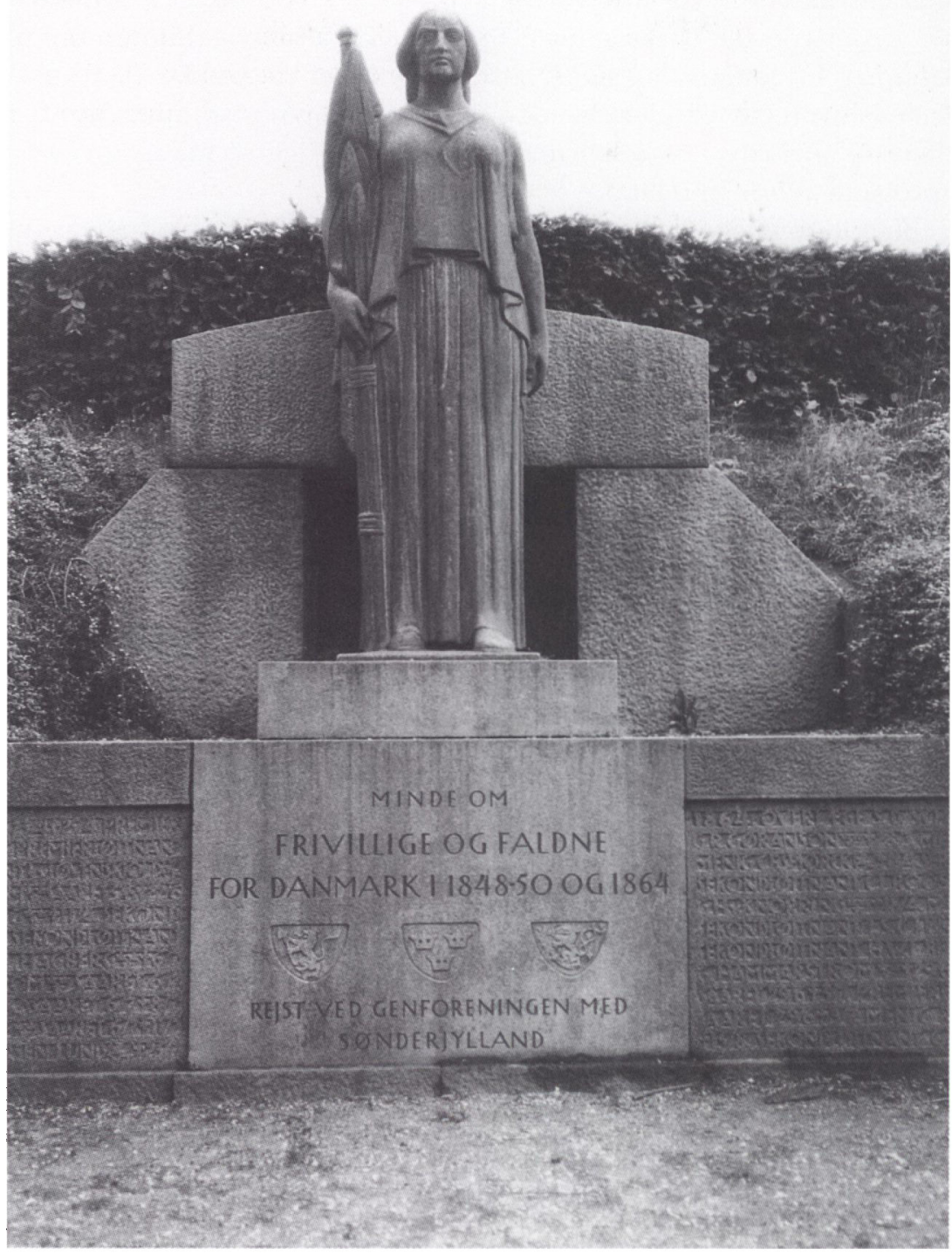

Monumentet $i$ Kastellet $i$ København for de nordiske frivillige i krigene 1848-50 og 1864. Foto Rolf Johansson. 
Men der fandtes en romantisk skandinavisme i Finland, som trivedes i de akademiske og intellektuelle kredse delvis opmuntret af eksilfinnerne i Sverige. Politisk var betydningen af den begrænset, men den gav stødet til en interesse og sympati for Norden. Den forholdsvis frisindede zar Aleksander II havde 1863 sammenkaldt den finske landdag, for første gang siden 1809 . I kølvandet var trykke- og pressefrihedsloven blevet liberaliseret, således at der på tidspunktet for den dansk-tyske krig fandtes ti finsksprogede og lige så mange svensksprogede aviser i Finland.

Blandt de finske dagblade viste især Helsingfors Dagblad åbent sin sympati for Danmark i den dansk-tyske krig, også i de ledende artikler. Andre aviser var mere forsigtige i deres ledere, men i rapporteringerne ser man ofte udtryk som "Danmarks retfærdige sag" og "tysk overgreb « samtidig med, at de finske frivillige omtales positivt bl.a. i Åbo Underrättelser, Mikkelin Wiikko-Sanomat og Päivätär. Kun den russiske generalguvernørs organ Finlands Allmänna Tidning tog stilling for tyskerne. ${ }^{3}$

I 1800-tallet ses flere eksempler på finner som deltagere i militære ekspeditioner i udlandet, altså uden for det russiske militærmaskineri. Der var finske frivillige blandt græske patrioter, garibaldister i Italien, nord- og sydstatssoldater i den amerikanske borgerkrig, maximilianister i Mexico og boere i Sydafrika. Der var selvfølgelig ikke tale om mange personer. Det viser dog, at der fandtes et grundlag for at optræde som frivillig. ${ }^{4}$ At der ikke deltog finner i Treårskrigen, skyldtes delvis, at »Europas mærkelige år« $1848 \mathrm{i}$ Finland blev en fredelig national manifestation, ikke en illoyalitetserklæring mod zaren. En anden vigtig årsag var, at der ikke var nogen hvervning. En sådan fandtes derimod i 1864 .

\section{Frivillige fra Finland}

De danske militærmyndigheder havde allerede før krigen forberedt sig på at modtage udenlandske frivillige. Ifølge en ordre af 27. januar 1864 skulle vedkommende medbringe et bevis for sine personlige forhold og "hæderlige vandel « og forpligte sig til at gøre tjeneste i den danske militærmagt $\mathrm{i}$ mindst et år. Officererne skulle indtræde på samme betingelser som de yngste danske officerer af samme grad. De, der ikke havde officerserfaring, måtte gennemgå en rekrutskole. Med hensyn til avancement betragtedes de frivillige som "staaende i 
overkomplet Nummer« og kunne vente forfremmelse efter de gældende regler. ${ }^{5}$

Krigen begyndte den 1 . februar 1864, og allerede 10 dage derefter startede fabrikant A. W. Möller fra Jönköping organiseringen af nordiske frivillige til den danske hær. Et antal svenskere havde allerede tidligere anmeldt sig. Også de finske volontører havde høje tanker om Möller. ${ }^{6}$

I Kobenhavn giorde den svenske diplomatiske repræsentant, minister, kammerherre $\mathrm{O}$. M. Björnstjerna også et stort arbejde til fremme af frivilligvirksomheden. Ifølge et mindeskrift fra 1919 „For Nordens Frihed" fortæller kaptajn H. A. Hanson, at der "baade i Norge, Sverrig og Finland dannedes Kommitteer, der indsamlede Penge og Beklædningsgenstande til Danmark. Og det var ikke blot i Storstæderne, det var snart i hver By«. Ifølge Åbo Underrättelser var der foretaget pengeindsamlinger i Borgå, Ekenäs, Jakobstad, Brahestad, Vasa, Alavo, Esbo, Helsingfors og Åbo. Danmark havde 11 honorærkonsuler i Storfyrstendømmet Finland, og flere af dem synes at have været centrale personer $i$ virksomheden. F.eks. i Helsingfors og Åbo blev der arrangeret "solidaritetsfester « til fordel for Danmarks sag. ${ }^{7}$

De nordiske frivillige fordelte sig som følger: svenskere 429 , nordmænd $144 \mathrm{og}$ finner 11. De finske frivilliges antal, elleve, blev allerede omtalt af A. W. Möller i 1864. Andre er kommet til lavere tal, f.eks. Christiansen \& Stevnsborg siger syv. I visse kilder bliver sekondløjtnanterne K. O. Carlsson og A. Sanmark nævnt som svenskere.

Det er muligt, at de svenske navne har skabt forvirring. Carlsson og Sanmark kom uden tvivl fra Finland. At nogle af soldaterne eventuelt boede i Sverige, kan også have indvirket. Som primus motor for hvervningen havde Möller et godt kendskab til de frivillige, også de finske. Hans oplysninger er bekræftet af senere forskning, bl.a. af jur.lic. Åke Backström. Følgelig kan vi med stor sikkerhed fastslå de frivilliges antal til elleve. ${ }^{8}$ 
De elleve finske frivillige var følgende:

\begin{tabular}{|c|c|c|c|c|}
\hline Navn & Sted & Erhverv & Tjenestetid & Rang/Regiment \\
\hline Boxberg, J. W. & Helsingfors & $\begin{array}{l}\text { fhv. } \\
\text { studerende }\end{array}$ & 9.6.-26.8.1864 & Menig/21 Inf.Reg. \\
\hline Carlsson, K. O. & Åbo & $\begin{array}{l}\text { skuespiller, } \\
\text { fhv. fænrik }\end{array}$ & 4.4.-1.9.1864 & $\begin{array}{l}\text { Sekondløjtnant/ } \\
22 \text { Inf.Reg. }\end{array}$ \\
\hline Dahlroos, E. H. & Åbo & $\begin{array}{l}\text { fhv. under- } \\
\text { officer }\end{array}$ & 30.4.-31.8.1864 & Sergent/ 22 Inf.Reg. \\
\hline Elenius, J. & Vasa & $\begin{array}{l}\text { fhv. under- } \\
\text { officer }\end{array}$ & 30.4.-31.8.1864 & $\begin{array}{l}\text { Korporal/ } \\
22 \text { Inf.Reg. }\end{array}$ \\
\hline Estlander, $\mathbf{R}$. & Helsingfors & studerende & marts-1.9.1864 & $\begin{array}{l}\text { Sekondløjtnant/ } 22 \\
\text { Inf.Reg. }\end{array}$ \\
\hline Forssell, H. & Helsingfors & grundejer & 18.4.-27.9.1864 & Menig/10 Inf.Reg. \\
\hline Liikanen, $\mathrm{H}$. & Kristina s. & $\begin{array}{l}\text { lærer, fhv. } \\
\text { underofficer }\end{array}$ & $\begin{array}{l}\text { marts 1864- } \\
\text { juni } 1865\end{array}$ & $\begin{array}{l}\text { Sergent / } 3 \text { Inf.Reg. } \\
\text { forfremmet: } \\
\text { sekondløjtnant }\end{array}$ \\
\hline Roos, J. M. & Åbo & kontorist & $9.6 .-23.8 .1864$ & $\begin{array}{l}\text { Menig/18 Inf.Reg. } \\
\text { \& Strejfkorpset }\end{array}$ \\
\hline Sanmark, A. & Helsingfors & fhv. løjtnant & april-okt. 1864 & $\begin{array}{l}\text { Sekondløjtnant/ } \\
2 \text { Inf.Reg. }\end{array}$ \\
\hline Saxberg, F. & Åbo & $\begin{array}{l}\text { handels- } \\
\text { rejsende }\end{array}$ & 9.6.-23.8.1864 & $\begin{array}{l}\text { Menig/18 Inf.Reg. } \\
\text { \& Strejfkorpset }\end{array}$ \\
\hline Søderlund, R. & Åbo & maskinist & 10.3.-22.8.1864 & $\begin{array}{l}\text { Menig/ } \\
\text { Strejfkorpset }\end{array}$ \\
\hline
\end{tabular}

Af disse elleve havde fem, d.v.s. Liikanen, Sanmark, Carlsson, Dahlroos og Elenius gjort tjeneste i zarens armé. Mens de andre måtte gennemgå et rekrutkursus (for studerende Estlanders vedkommende et officerskursus), kunne de fhv. militærfolk sendes direkte til fronten. Her skal fremhæves, at de var forhenværende militærfolk, d.v.s. de havde forladt aktiv tjeneste. Ingen aktive militærfolk meldte sig som frivillige for Danmark. Dette beroede på to årsager. Det kunne indebære visse risici for den fremtidige karriere at gøre det, eftersom den russiske regerings sympatier var på den tyske side. Desuden var det af samme årsag umuligt at få orlov fra krigstjeneste. Det kunne professionelle militærfolk nemlig få i Sverige, indtil regeringen i Stockholm til sidst måtte bøje sig for de stærke preussiske forestillinger og inddrage orlovene. ${ }^{9}$

Hvordan var så den russiske regerings holdning til de finske frivillige? At virksomheden var kendt af myndighederne, det stod klart; de kunne jo bare læse de finske aviser, som åbent skrev om de frivillige ved navns nævnelse. De eneste eksempler på trakasserier kommer fra København, hvor den russiske ambassadør efter sigende havde 
forsøgt at hindre Estlanders fuldførelse af officerskursuset og Liikanens forfremmelse på sygelejet til sekondløjtnant. ${ }^{10}$

Nogen praktisk betydning fik disse indgreb ikke: Estlander blev dansk officer og Liikanen forfremmet. I praksis forholdt russerne sig passivt til finnernes engagement for Danmark. Årsagen hertil var formodentlig først og fremmest, at Rusland tolererede tjenesten som frivillig så længe den var så pas begrænset og ikke gav politiske problemer. Mens redaktøren af Åbo Underrättelser blev anklaget for en kritisk artikel mod den russiske krigsførelse i Polen, kunne et solidaritetsmøde for de faldne danske soldaters enker og børn den 19. marts holdes uhindret i Helsingfors Universitets festsal. Dertil kommer, at de frivillige ikke blev trakasseret af myndighederne, da de vendte hjem til Finland efter krigens ophør. ${ }^{11}$

De frivilliges gennemsnitsalder var 27 år, Sanmark som den ældste var 35 og Saxberg som den yngste 21 år. De kom som regel fra middelklassen. Dahlroos og Saxbergs fædre var ganske vist husmænd, men selv havde de opnået "respektable“ stillinger inden for militæret og erhvervslivet. Studenten Estlander stammede fra en fremtrædende kultur- og akademikerslægt, som senere blev adlet. Sanmarks far var kæmner ved postvæsenet, selv uddannede han sig til skovrider. Carlsson - søn af en jagtfoged - havde efter soldaterlivet prøvet sig frem som skuespiller, men kom til at afslutte sin karriere som rådmand i Uleåborg. De øvrige havde en militær, kirkelig eller kommerciel baggrund. ${ }^{12}$

Det var også naturligt, at volontørerne kom fra Helsingfors og Åbo. Flere af dem var ganske vist født ude på landet, men skolen og arbejdet forte dem til byerne, hvor der var en akademisk tradition med debatterende, internationalt orienterede studenterklubber eller finske militærsammenslutninger, hvor man også fulgte med i krigene ude i den store verden.

Herman Liikanen var utvivlsomt den mest farverige blandt volontørerne. Han var født 1835 i Kristina sogn i St. Michels len (amt), faderen var graver. Herman viste anlæg for studier, selv om han aldrig tog studentereksamen, og ernærede sig som huslærer. Allerede i sine unge år havde han som sin ledestjerne antaget nationalismen, som han aldrig i hele sit lange liv ( 91 år) svigtede. I tyve års alderen havde han ladet sig hverve til hæren og havde været med til at forsvare Fredrikshamn mod briterne under Krimkrigen. Han deltog også som "garibaldist « - i den italienske frihedskamp 1860-61, selv om han 


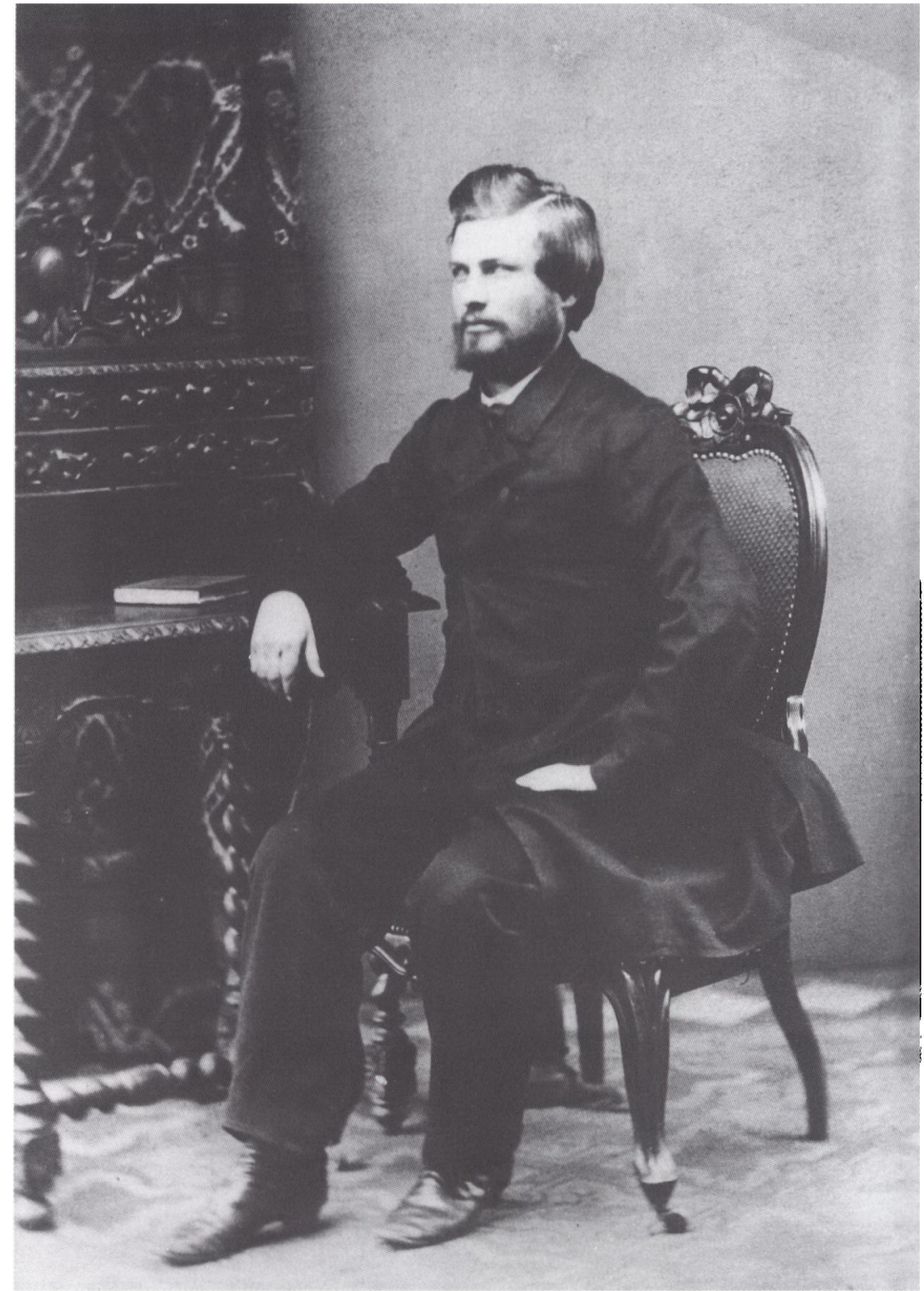

Herman Liikanen, f. 1835, var lærer og fhv. underofficer. Han tiente 1864 som finsk frivillig ved 3. infanteriregiment, forst som sergent, senere forfremmet til sekondløjtnant. Han blev såret ved Dybbol 18. april 1864. Foto i Museet på Sonderborg Slot. 
aldrig nåede ud til selve fronten, men måtte nøjes med at vogte fanger i den ungarske legion. Efter hjemkomsten til Finland 1862 arbejdede han som assistent hos oberst Alex. Theslöf på Sveaborg, indtil »Danmark kaldte ${ }^{13}$

Liikanen var gennem sine nationalistiske taler og skrifter kendt i de politiske kredse i Helsingfors, der 1863-64 vejrede liberal morgenluft $i$ landdagen. Liikanen kunne regne med (uofficielle) rejsebidrag fra borger- og bondestandens repræsentanter. Han havde tillige kontakt med ledende skandinavistkredse i Sverige, hvilket under rejsen til Danmark resulterede $i$ en audiens hos den svenske konge i Stockholm. ${ }^{14}$

Estlander og Sanmark var med i de liberale studenter- og medborgerkredse i Finland og havde klare ideologiske motiver for deltagelsen, en afsky for stormagtsovergreb, en tro på de små nationers ret og en glødende nationalisme. Trods sin "praktiske" baggrund som officer og skovtekniker var Sanmark en stor idealist. Hans breve er besjælede af kamp- og offervilje:

"Da jeg rejste ... så jeg ikke andet end et lille folk, der kæmpede mod en overmagt, og jeg fandt det så stort, så poetisk, at jeg fik lyst til at være med. Mit liv var ikke så meget værd, hvorfor så skåne det? Jeg tog afsted, fast besluttet på ikke at vige et skridt, ikke at sky nogen fare ${ }^{15}$

Der var også en ordentlig portion eventyrlyst i Sanmark og Estlander. De tog afsted delvis uden familiernes viden eller accept. Andres motiver bestod af arbejdsløshed og lede, f.eks. var K. O. Carlsson blevet afskediget fra hæren og førte efter sigende et "ulykkeligt liv« som skuespiller. ${ }^{16}$

\section{Til Danmark!}

Den 11. februar havde Herman Liikanen og Rudolf Josef Estlander begivet sig ud på en lang og besværlig rejse over Åland til Sverige med Danmark som mål. Af frygt for indgriben fra den russiske regerings side havde de besluttet at rejse det første stykke hver for sig. Liikanen kom til Åbo den 12. februar og blev af en sympatisør, postbud Bergström ved Åbo posthus henvist til gæstgiveriet i det nærbeliggende Myynämäki. Der stødte Estlander til. De tog derfra sammen over Bergö til Åland. 
ÅU kunne fortælle, at "Ålands Havet var fyldt af drivis og stormfuldt, nogle steder åbent, andre steder belagt med et tyndt lag af is, som brast under deres fødder. De måtte derfor tage lange omveje og ofte vende om for at vente på gunstigere forhold «.

De ugunstige vejrforhold tvang de to til at blive på Åland til den 26. februar, inden de kom afsted og den efterfølgende dag kunne nå Grisslehamn på den svenske side. De fortsatte derfra direkte til Stockholm, hvor Liikanen overnattede hos bekendte, mens Estlander tog på hotel.

De to »eventyreres" ankomst var blevet observeret af den svenske presse og det var under dette ophold i Stockholm, Liikanen blev bevilget audiens hos kong Karl XV. Kronprins Oscar var også til stede og Liikanen blev nøje udspurgt om forholdene i Finland.

I begyndelsen af marts var de begge nået til København. I et brev af den 10. marts meddelte Liikanen, at han den 6.3. var blevet antaget som underofficer (sergent) i den danske hær, nærmere bestemt 3 . regiments 2. kompagni. Mens Liikanen umiddelbart blev sendt til fronten, måtte Estlander begynde på et militæruddannelseskursus på rekrutog officeraspirantskolen i København. ${ }^{17}$

Den 4. april kom der yderligere to finske officerer til Danmark. Det var K. O. Carlsson og Anton Sanmark. De havde begge gjort tjeneste i den russisk-finske hær, Carlsson som fænrik i Åbo inddelte Skarpskyttebataljon, Sanmark som løjtnant i Sapørbataljonen i Helsingfors. De fik tildelt dansk sekondløjtnantsgrad.

Eftersom myndighederne i praksis ikke chikanerede de frivillige, dristede de senere volontører sig til at foretage rejsen mere bekvemt d.v.s. med båd til Danmark! For at få udrejsetilladelse, altså pas, måtte man opgive formålet med rejsen, men dette kunne ganske enkelt omgås, d.v.s. man opgav en falsk rejseårsag.

Den 16. marts var studenten Herman Johan Boxberg sejlet med skonnerten »Ored « fra Åbo til København sammen med sin far, fhv. underofficer i den finske garde, H. V. Boxberg og en dansk feltskær ved navnet Fischer, der efter det oplyste var blevet dekoreret med dannebrogskorset (formodentlig under Treårskrigen). Vel ankommet til Kobenhavn gik far Boxberg ikke i dansk militærtjeneste, men sønnen blev sat på rekrutkursus. - Ti dage senere afrejste de to handelsrejsende, Johan Michael Roos og Frederick Saxberg, samt den ældre underofficer i den inddelte hær, Erik Henrik Dahlroos fra Åbo. I Göteborg slog de sig sammen med et antal svenske frivillige og rejste den 
7. april til København, hvortil de ankom den 8. De to førstnævnte finner måtte blive på en rekrutskole i København, mens Dahlroos den 30.4. blev indrulleret som sergent og sendt til Als. ${ }^{18}$

\section{I felt og kaserne}

De frivillige skulle melde sig hos krigsministeriet i København, hvor deres duelighed blev vurderet. Dokumenteret tidligere militærtjeneste muliggjorde en hurtig flytning til fronten. F.eks. Liikanen kom afsted praktisk talt straks, mens Carlsson og Sanmark blev noget længere i Kobenhavn.

For de ikke-militært uddannede fulgte derefter et kursus, et kortere for de menige, et længere for officererne. Estlander fortalte åbenhjertet -og afslørende - om, hvorfor han valgte det længere:

»Hvis man fik lov til at blive volontør $i$ ordets franske betydning, var jeg ikke blevet her en eneste uge, men siden denne post $\mathrm{i}$ året $48 \mathrm{blev}$ afskaffet og man nutildags kun må indgå som nummerkarl (menig), har jeg hellere valgt denne visselig dyrere og længere, men som jeg tror, for mig Eneste mulige vej. Mulig kun i den forstand, at jeg herigennem kan undgå sygelazaretterne, hvilke ikke så meget frekventeres af blesserede (sårede) men desto mere af brystsyge $i$ alle stadier, syge som følge af at marchere med en tung oppakning under fugtige og ugunstige vejrforhold. Det er denne oppakning, jeg frygter mere end døden, og det er derfor, jeg har valgt denne udvej«.

Estlander ønskede altså bestemt ikke at tilhøre fodfolket. Men det tog tid at blive officer, selv om han gennem "punktlighed og påpasselighed " forsøgte at overbevise uddannelsesofficererne om, at han efter nogle dage var rede til tjeneste. Udnævnelsen trak ud. Først mente Estlander, at det skyldtes uddannelsesofficerernes bureaukrati og dovenskab, senere en indblanding fra den russiske legationschefs side. Således fordrev han tiden med ti timers daglig eksercits bevæbnet med »en lille, net, ca. 14 skålpunds muskedonner «.

De finske officerer var fortrolige med de danske militærgeværer (Tapriffel M/1848, Minieriffel M/1822). Der var blevet brugt tilsvarende $\mathrm{i}$ den russiske hær, derimod ikke lige netop bagladegeværer. Også studenter som Estlander var ofte velbevandrede i skydevåben ("en bøsse var ikke noget for mig ubekendt instrument«). Han skød nemlig meget godt. Men desværre blev den eneste smag af krig, Est- 


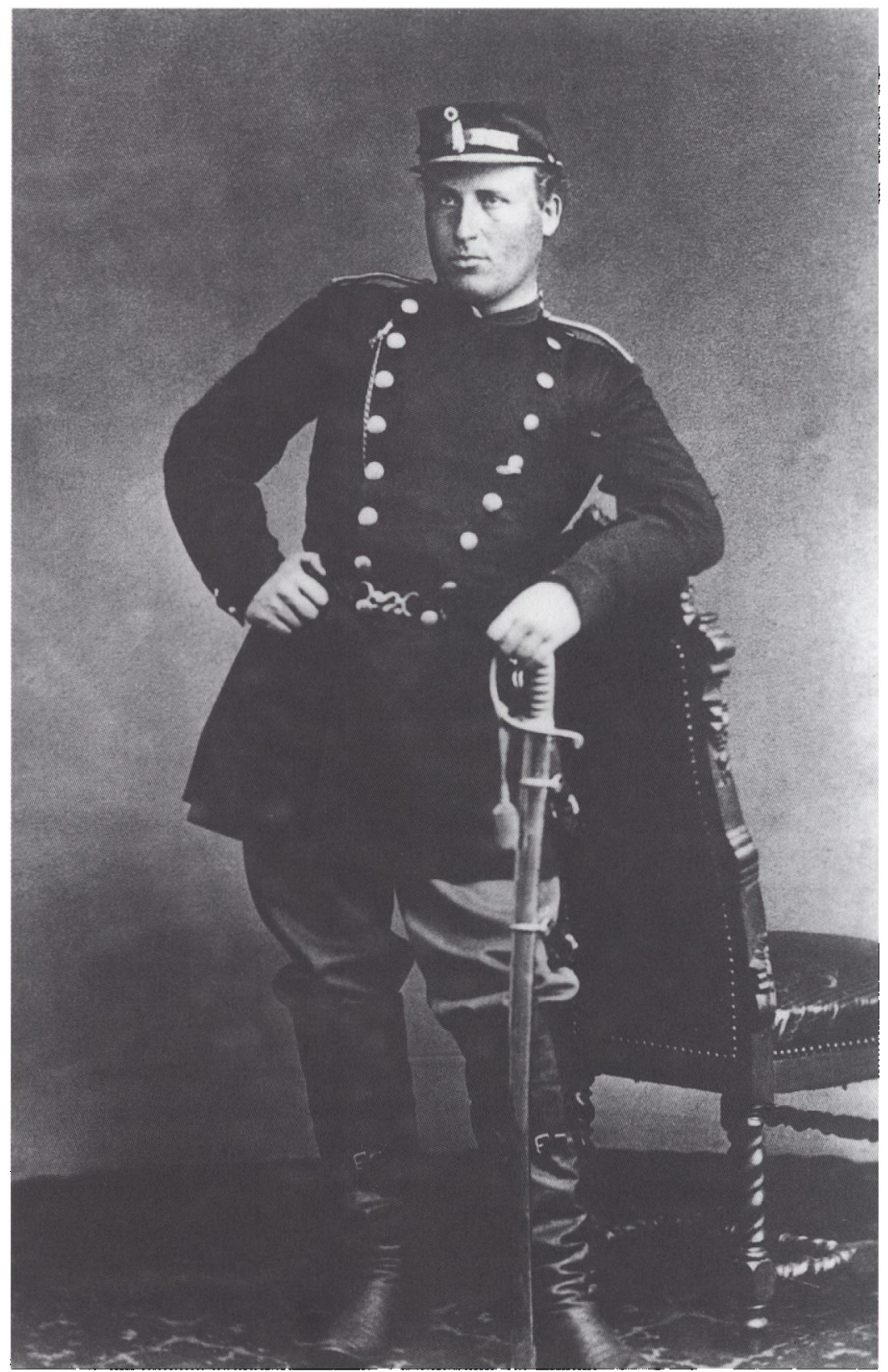

Rudolf Josef Estlander var studerende og tjente 1864 som frivillig ved 22. infanteriregiment med rang af sekondløjtnant. Foto $i$ Museet på Sønderborg Slot. 
lander fik, en "studietur « - Sanmark kaldte den en anelse spydigt en "fornøjelsestur« - med A. W. Möller til Dybbøl i påskehelligdagene. Estlander noterede følgende:

"Langfredag (25.3.) fik jeg for første gang chancen at stifte bekendtskab med granater, af hvilke der i 1 times tid fløj 139 over hovedet på os og slog ned på en skanse Nr. 6, som lå 80 skridt længere ude end den, hvor jeg befandt mig. Dagen derpå havde jeg fornøjelsen at høre nogle mineur(?)kugler hvine forbi ørene på mig. Dette var også næsten alt det rent krigsmæssige“.

Den 9. maj blev Estlander udnæunt til sekondløjtnant, men da var fjendtlighederne allerede blevet indstillet. Estlanders kommentar var følgende: »Forbandet at Danmark er gået med til våbenstilstanden, for nu sker der jo intet $\mathrm{i}$ en måned, men jeg vil håbe, at det derefter vil gå desto mere hidsigt til«.

Som fhv. officer behøvede Sanmark kun at indlevere en kort ansøgning med vedlagt tjenestefortegnelse. Han konstaterede:

"Jeg gjorde ikke fordring på andet end at komme ind med en officersgrad, og der blev lovet svar snarest muligt. Det kom også dagen efter, og til min store glæde er jeg nu ansat som ældste sekondløjtnant i Det kgl. danske Infanteri, hvortil jeg også havde ønsket, samt har at indfinde mig på højkvarteret i Sønderborg.

Hvis jeg ikke var tvungen til at vente på et svar fra London (i spørgsmålet om livsforsikring i tilfælde af krig), så ville jeg allerede være på vej. At ligge her og læse reglementet samt se på eksercitsen, det er der nu ikke tid til. Min uniform er allerede bestilt, en revolver købt, og som sagt er, rejser jeg straks, når jeg får besked“.

Under ventetiden i Kobenhavn boede han - sammen med Estlander og Carlsson - på det fashionable hotel d'Angleterre. Om livet i byen skrev han, at selv om krigene påvirkede tilværelsen, var der godt med mad og drikkelse. Hele København fulgte helt naturligt med i krigen:

"I går var jeg vidne til to faldne officerers begravelse. Kisterne var overdækket med blomster og en stor menneskemængde ledsagede de faldne krigere til graven «.

Sanmark deltog også i forlystelseslivet i København. Han var specielt betaget af teaterlivet og var især glad for, at det finske skuespil "Kan ej“ (af J. L. Runeberg) fandtes på teaterrepertoiret. Han var meget til- 
freds med forestillingen. "Stykket blev udført på en måde, som intet lod tilbage at ønske ${ }^{19}$

Da de finske frivillige ankom til Danmark, havde krigen været i gang siden februar måned, og de danske tropper befandt sig i en vanskelig situation.

For ikke at blive omringede via fløjene, havde danskerne næsten umiddelbart måttet opgive den oprindelige forsvarslinje ved Dannevirke i Slesvig. Den danske øverstbefalende general Chr. J. de Meza gennemførte en defensivt dygtig retræte til Dybbøl, hvor man påbegyndte et intensivt arbejde for at forstærke de $\mathrm{i}$ årevis forsømte forsvarsanlæg. Følgen af retræten var, at de østrigske styrker kunne trænge dybt ind i Midtjylland, mens de preussiske forfulgte de danske tropper til Dybbøl. Retræten kostede de Meza stillingen som øverstbefalende; han blev afløst af generalløjtnant Georg Gerlach. Ved de finske soldaters ankomst til Dybbøl stod preusserne allerede foran skanserne. Liikanen var kommet til Als den 14. marts, og allerede to dage derefter deltog han i skærmydslerne ved Dybbøl.

Sanmark skrev: »Ingen havde dog hellere end jeg villet deltage i en om end den mindste skærmydsel. Første morgen jeg var i løbegraven, hvinede kuglerne omkring os, men de gjaldt ikke os men vore forposter, som da blev trængt sammen inde i skanserne. Derefter var det blot at sidde helt pænt inde og bare tage imod kuglerne ${ }^{20}$

Carlsson og Sanmark anmeldte sig sammen ved overkommandoen på Als og fik tildelt deres enheder, 22Inf. 3 respektive 2Inf.6. De blev meget vel modtaget af deres danske overordnede, og de havde også en meget høj opfattelse af deres danske kollegaer:

"Jeg sætter de danske officerer i almindelighed meget højt og tror, at intet lands officerskorps kan måle sig med det danske hverken $i$ uddannelse eller i duelighed «,

mente Sanmark. Også den danske soldats udholdenhed og mod vakte hans beundring:

"Af 9 døgn er han seks i tjeneste, og nogen hvile om natten er da utænkelig. Om dagen er det tilladt for ham at hvile, og uanset at han hvert minut kan vente sig en granatsplint, så synes han dog at sove ganske godt $\ll .21$ 


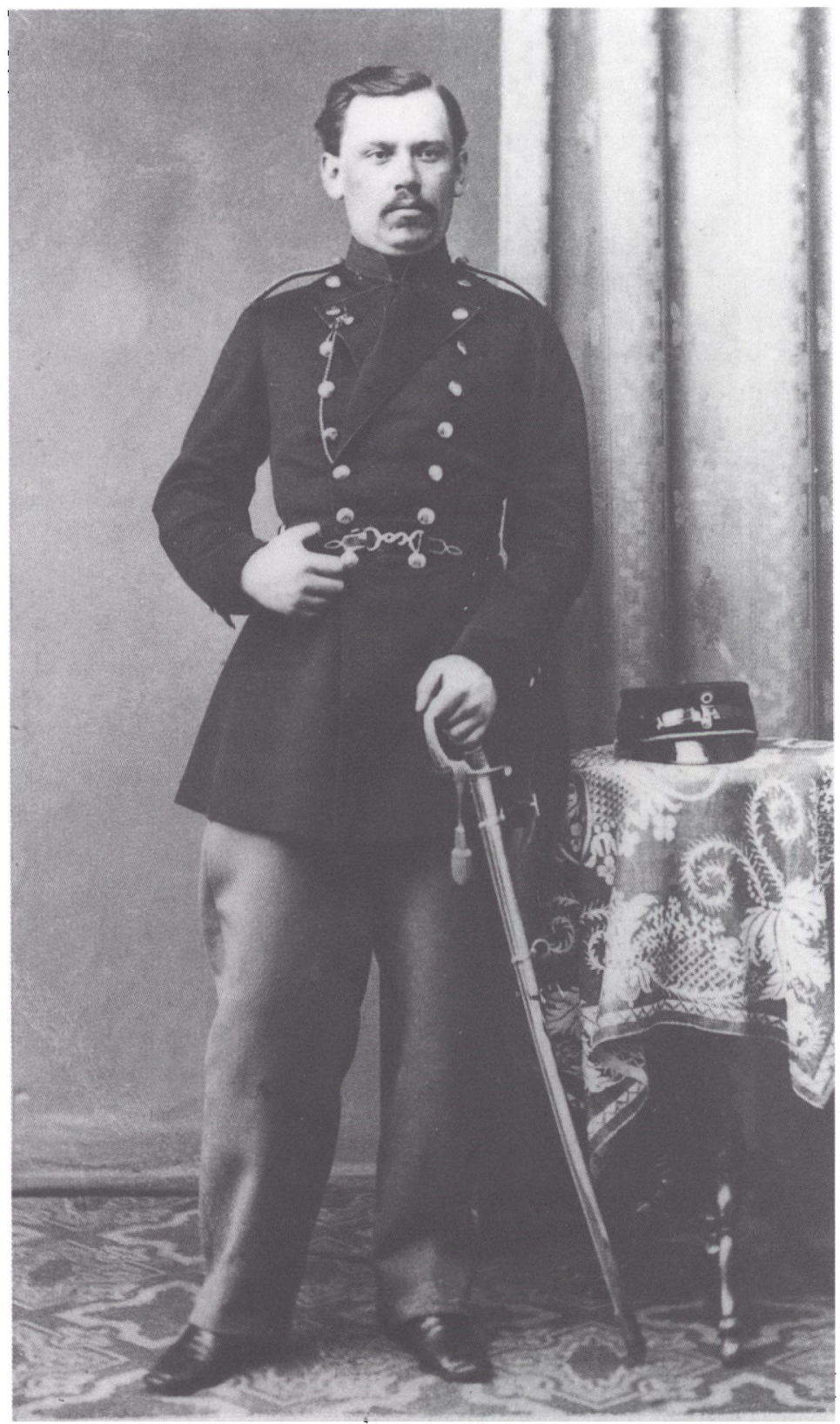

Anton Sanmark var fhv. lojtnant og tjente 1864 som finsk frivillig med rang af sekondløjtnant ved 2, infanteriregiment. Foto i Museet på Sonderborg Slot. 
De finske officerer så også ud til at trives blandt deres danske kollegaer. Især Carlsson vandt respekt blandt sine officerskollegaer og soldater. $^{22}$ Derimod synes Sanmark ifølge sin kompagnichef, premierløjtnant Gandil at have haft visse problemer, specielt med sproget, noget som dog blev set $i$ et mildere lys, da finnen kun havde været $i$ regimentet i 8 dage. ${ }^{23}$

Forsvaret ved Dybbøl bestod af to forskansede linjer (I-VI og VIIIX), som blev udsat for svær artilleri-ild fra preussernes side:

"Det var et storslået skuespil, da jeg fra mit leje med ansigtet vendt mod himmelen betragtede, hvordan fjendens kugler haglede over os og hvorledes vore egne Als-batterier sendte granater og raketter over vore hoveder tilbage mod fjenden«,

reflekterede Liikanen. ${ }^{24}$

Forsvarerne arbejdede febrilsk natten igennem med at reparere de skader, preussernes granater og kugler havde forvoldt $\mathrm{i}$ dagens løb. De finske officerer var utilfredse med den danske forsvarsstrategi og -taktik. Den var alt for passiv:

"Noget der falder mig ubegribeligt, er at danskerne lader fjenden husere næsten efter behag uden hverken at gøre et udfald eller beskyde ham. De skud der løsnes, rettes hovedsagelig mod hans batteri, mens han selv ugeneret i større troppemængder rører sig på en afstand, hvortil man meget vel kunne nå med kartæsker«,

skrev Sanmark. ${ }^{25}$

\section{Dybbøl den 18. april}

Preusserne besluttede sig til at angribe den 18. april. Deres stormgrupper lå i løbegrave og s.k. paralleller kun 300 meter fra de danske linjer. De havde 37.000 udhvilede tropper, hvoraf alene stormtropperne, 10.000 , var næsten lige så mange som danskerne totalt. Af forsvarere var der altså kun 11.000, omkring 5.000 i linjen og 6.000 i reserve.

Klokken 04.00 åbnede de preussiske batterier en veritabel trommeild mod de danske stillinger, en kanonade der varede i seks timer.

I et brev dateret den 17. april havde Carlsson skrevet:

"... Fire døgn uden et øjebliks søvn og tilbragt under åben himmel. Vore skanser skyder ikke mere, vort artilleri kan ikke måle sig med 
fjendens. I aften (den 17.) trækker vi os tilbage til Dybbølspositionen. Vi venter i disse dage et stormangreb. Lever jeg efter det, så skriver jeg«. ${ }^{26}$

Et dansk morterbatteri i II skanse holdt ud og preusserne rettede deres ild mod dette - hvilket blev skæbnesvangert for den ved denne skanse posterede 22Inf.3 - og Carlsson!

Tredje kompagni havde måttet trække sig tilbage for at hvile ud, så kompagnichefen befandt sig for ordregivning tidligt om morgenen $i$ en løbegrav sammen med seks andre officerer. Kl. 06.00 slog en granat, som var beregnet for nævnte morterbatteri, ned i brystværnet og splinterne regnede hen over officererne. To officerer blev dræbt på stedet, mens tre andre, bl.a. Carlsson, blev såret. Finnen fik sår i hovedet og skadede tillige hoften. Han blev hurtigt ført til Sønderborg og derfra siden til videre behandling i København. ${ }^{27}$

Præcis kl. 10.00 blev bombardementet indstillet, og de preussiske tropper stormede op fra løbegravene og "parallellerne«. På tyve minutter erobrede preusserne de tre sydligste skanser!

Skanserne IV-VI blev ligeledes udsat for massive angreb. Sanmark havde som delingschef for 2Inf.6 ansvaret for forsvaret af VI skanse. Ved angrebets begyndelse befandt han sig i løbegraven mellem $\mathrm{V}$ og VI skanse. Så blev han beordret til at vende tilbage til sin post i skansen. Under bombardementet havde denne været praktisk taget tom, og Sanmark havde store problemer med at få samlet forsvarerne. $\mathrm{Da}$ han havde fået samlet et antal af fyrretyve, var de første preussere af seks kompagnier på ca. 1.000 mand - allerede i skansen. Overmagten var for stor. De forsvarere, der ikke faldt, blev taget til fange. Blandt fangerne fandtes også Sanmark. I et brev fortalte han:

"Min kompagnichef råbte til mig: alt er tabt og strakte sin sabel frem, for ikke unødigt at ofre dem der endnu var tilbage af vore raske folk. Jeg kunne ikke andet end blot at følge hans eksempel. Kampen standsede, og jeg er krigsfange efter kun én uge i ilden. Hårdt nok! « ${ }^{28}$

På en halv time var danskernes sydfront smuldret. Hvis det lykkedes fjenden at nå Als Sund, risikerede hele nordfronten at blive omringet. Samtidig fortsatte den preussiske oprulning af forsvarslinjen.

Siden $\mathrm{kl}$. 04.00 havde tredje infanteriregiment (inklusive andet kompagni og Herman Liikanen) stået $\mathrm{i}$ reserve bag ved linjerne. Straks efter kl. 10.00 kom et ilbud med oplysningen om, at preusser- 


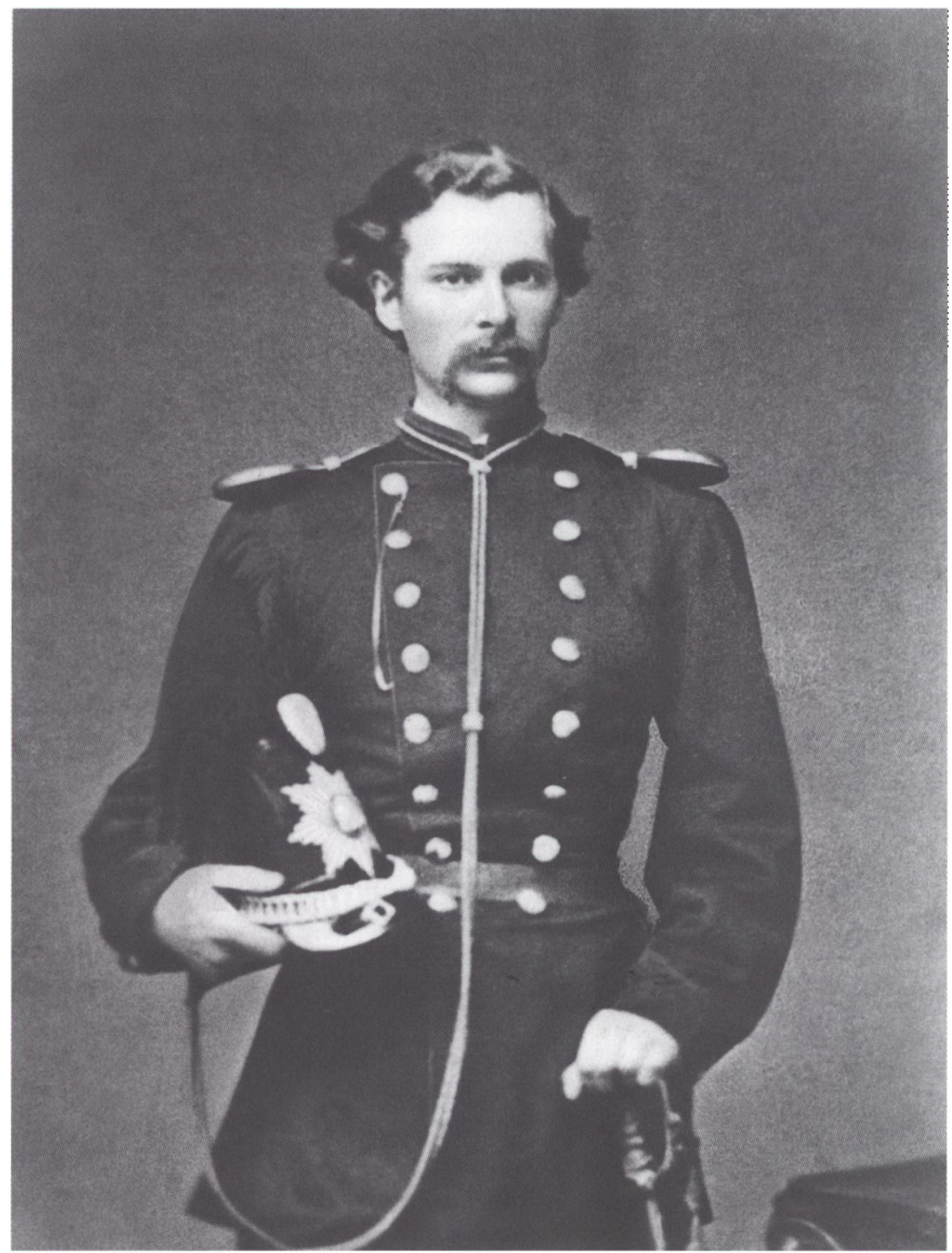

K. O. Carlsson var skuespiller og fhv. frenrik. 1864 tjente han som finsk frivillig ved 22. infanteriregiment med rang af sekondløjtnant. Han blev såret ved Dybbol 18. april 1864. Foto i Museet på Sonderborg Slot.

nes stormangreb var begyndt. En halv time senere fik 3Inf. ordre til at rykke frem mod skanserne IX og X. Man avancerede hurtigt - "vi stormede under hurraråb « - og fik kontakt med de preussere, der 
stormede ud fra den erobrede ottende skanse. Kampen blev hård. Liikanen faldt om, slemt tilredt $i$ låret af et geværskud.

På samme tidspunkt havde den danske hærs ottende brigade på ca. 6.000 mand i reserve kastet sig ind i kampen, understøttet af panserskibet »Rolf Krake«, som var dampet ind i Vemmingbund og havde beskudt fjendens stillinger. "Den heroiske kontra-attak " - senere kanoniseret af kunstnere - løb visserlig ud $i$ ingenting og påførte ottende brigade svære tab $\mathrm{i}$ døde, sårede og tilfangetagne, men den muliggjorde alligevel en disciplineret retræte over Als Sund.

På slagmarken lå også Herman Liikanen:

»Preusserne var allerede på en afstand af tyve skridt. Skønt såret forsøgte jeg at slutte mig til de forbi os retirerende danskere, da en officer ved det 16. regiment råbte: "der er en såret af vore egne" og bad en soldat om at ledsage mig. Denne greb mig kraftigt under armen og jeg fulgte nu med resterne af de danske regimenter til Sønderborg «.29

K1. 14.00 var slaget slut - selv om de danske batterier ved Als Sund og de preussiske i Sundeved udkæmpede en artilleriduel den resterende del af dagen.

Preussernes sejr var overvældende. Mens de kun havde mistet 263 som døde og 909 sårede, var 808 danskere faldet, 910 sårede, 2872 taget til fange og 215 var meldt savnede.

\section{Efter Dybbøl}

Efter nederlaget ved Dybbøl måtte danskerne rømme deres sidste stærke fæstning Fredericia og trække sig tilbage til det nordligste Jylland. Den 24. april var en fredskonference blevet indledt i London, men fjendtlighederne skulle yderligere stå på i tre uger, for man opnåede våbenhvile den 12 . maj.

I Finland forsøgte f.eks. Åbo Underrättelser at nedtone nederlaget ved Dybbøl: "Danskernes tab i striden ved Dybbøl opgives (ifølge »et øjenvidne«) til langt mindre end aviserne hos os har angivet dem at være $«{ }^{30}$ Da postgangen fra Danmark til Finland var langsom og den internationale telegrafi opererede via Skt. Petersborg, havde nyheden næppe nogen betydning for de frivillige, som endnu ikke var nået til fronten. De var ved nyhedens ankomst til Finland enten undervejs til eller befandt sig allerede i Danmark. Muligvis havde Dybbølnederla- 
get og den kommende våbenhvile dog en hæmmende virkning på den fortsatte hvervning.

Forhandlingerne i London førte ikke til noget resultat, og våbenhvilen sluttede den 26. juni. Danmark mobiliserede, og de finske soldater fulgtes med deres enheder til nye posteringer. Estlander fik sin officersfuldmagt den 9. maj og blev som sekondløjtnant kommanderet til det 22. regiment, som befandt sig på Fyn. Carlsson vendte i begyndelsen af juni tilbage til samme enhed, hvor også sergent Dahlroos og korporal Elenius gjorde tjeneste. Den 9. juni forlod menig Boxberg rekrutkursuset $\mathrm{i}$ København for at blive udstationeret sammen med det 21. regiment $i$ Vendsyssel i det nordlige Jylland. Hans kursuskammerater, menige Saxberg og Roos, blev derimod den 9. juni overført fra rekrutskolen først til det 18. regiment og derfra den 26 . juni - den dag, våbenhvilen udløb - til Aarøes strejfkorps på Als.

Aarøes strejfkorps var blevet grundlagt i marts 1864 som en let, rørlig enhed med den opgave at rekognoscere og slå til bag fjendens linjer. Korpsets kommandant var infanterikaptajn Aarøe - en veteran fra Treårskrigen. Det første kompagni blev ledet af løjtnant ved Kalmar-regimentet Friherre Hugo Raab og bestod for en stor del af nordiske frivillige. Det var dette strejfkorps, den 25-årige maskinist Robert Söderlund fra Åbo sluttede sig til. Han meldte sig den 10. marts og blev menig i strejfkorpset. ${ }^{31}$

Før Dybbølslaget havde strejfkorpset udført et antal attakker mod preussiske mål. Strejfkorpset var upopulært blandt tyskerne. Det blev ikke opfattet som en almindelig enhed men som en partisanbande. Desuden var de deltagende svenskere - af udenrigspolitiske årsager en torn i øjet på tyskerne. ${ }^{32}$ Det vides ikke, om Söderlund deltog i aktionerne. Derimod findes der et notat om, at han den 31. juli 1864 efter egen begæring blev bevilget afsked fra den danske hær. ${ }^{33}$ Under våbenhvilen fik strejfkorpset forstærkning fra andre omorganiserede regimenter. Det nordiske indslag blev stærkt. Korpset kom dog til at spille en forholdsvis tilbagetrukken rolle, efter at fjendtlighederne blev genoptaget. Der findes heller ingen oplysninger om Saxbergs og Roos' militære »bedrifter«. Deres tjeneste ophørte den 22. august 1864, d.v.s. samme dag, Aarøes strejfkorps blev opløst.

Menig H. Forssell fra Helsingfors gjorde tjeneste i det 10. regiment på Als, og han fik sin "ilddåb“ den dag, fjendtlighederne igen brød ud. Det næste mål i den preussiske strategi var nemlig Als. Natten til den 29. juni gik de preussiske tropper over Als Sund i et angreb, som 

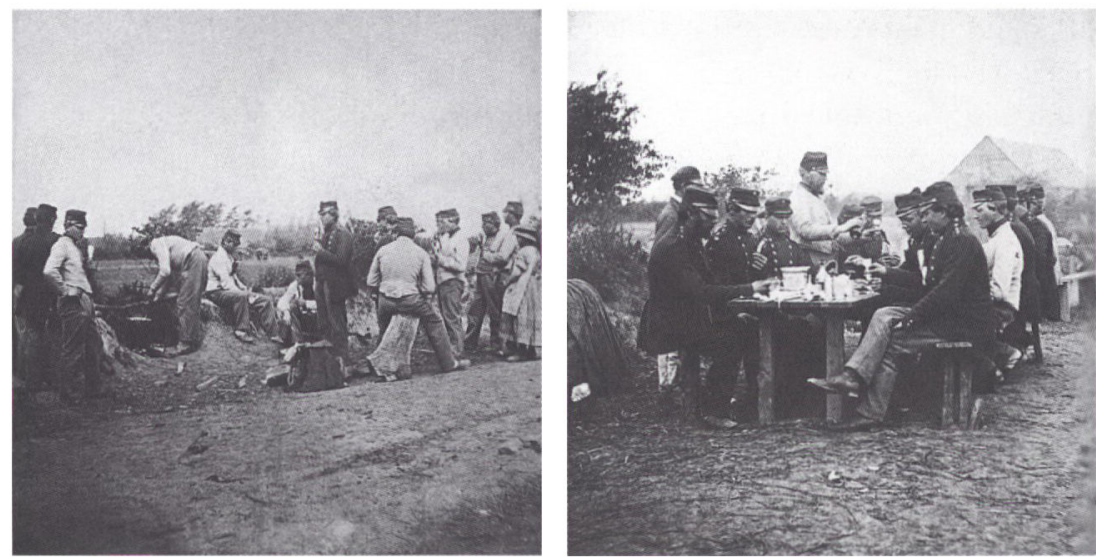

Soldater i krigen 1864. Fotos i Dansk Centralbibliotek for Sydslesvig.

kunne være endt med en katastrofe for dem, da »Rolf Krake» befandt sig i sundet parat til at skyde landgangsfartøjerne i sænk. En misforståelse førte dog til, at panserskibet trak sig tilbage, og preussernes offensiv kunne fortsætte. Trods heltemodigt forsvar kunne danskerne ikke holde Als, men måtte den 1. juli retirere til Fyn. Forssell bestod sin ildprøve med hæder. Bataljonchefen kaptajn $O$. Vaupell roste finnens indsats i striden. De danske tab i døde, sårede og tilfangetagne blev 3.000, mens preusserne kun mistede $300 .{ }^{34}$

De danske stillinger i Nordjylland blev også mere og mere trængt af fjenden. Allerede før våbenstilstandens ophør var en stor del af den danske styrke blevet overført til Fyn for at deltage i forsvaret dér. Blandt de evakuerede var det 21. regiment og menig Boxberg. Resten af de danske tropper forsøgte at gøre sig gældende mod fjendens overmagt, men den 10 . juli besluttede den danske militærledelse sig til at samle hele hæren til Frederikshavn for evakuering til Fyn. Hele Jylland befandt sig i preussernes og østrigernes hænder.

Det danske forsvar - ca. 40.000 mand - blev nu koncentreret på Fyn, som var preussernes næste mål. Finnernes enheder var stadig mobiliserede, men i nogen egentlige kampe nåede de ikke mere at deltage. De danske militærfolk ville slås, men politikerne ville have fred. Den 12. juli bad en nyudnævnt dansk regering om fred. Der blev indført våbenhvile den 20 . juli, og ved månedsskiftet påbegyndtes fredsforhandlingerne $i$ Wien.

Danmark havde tabt krigen. Sanmark havde en klar opfattelse af 
årsagen: Danskerne var underlegne ikke kun i antal men også i artilleri og teknisk udrustning. Deres gammeldags forladere kunne ikke måle sig med det moderne preussiske tændnålsgevær. ${ }^{35}$

\section{Lazaretter og krigsfangenskab}

De feltsanitære forhold var i princippet ikke værre i Danmark end i andre lande. Det værste var, at skydevåbnenes ildstyrke var blevet overordentlig meget større samtidig med, at den militære strategi var forblevet uændret - med ufattelig blodsudgydelse til følge. Lægemiddelkunsten kendte endnu kun lidt til bakterier og sårinfektioner. Amputeringskniven eller -saven var ofte lægernes eneste redskab, og operationerne blev udfort $\mathrm{i}$ hast, ofte under uhygiejniske forhold.

Den kugle, der ramte Liikanen, var gået igennem det højre lår og havde beskadiget senerne, men kun rørt benet ubetydeligt. Soldaten, som hjalp Liikanen fra slagmarken, blev selv såret af preussernes granatild, og finnen blev liggende på torvet i Sønderborg. Feltpolitiet samlede de sårede op fra torvet. Liikanen blev i en sygetransportvogn ført til Høruphav, hvor det norske dampskib "Nordenstjerna« tog ca. 500 sårede ombord for at føre dem til København. Her var der en sengekapacitet på 9.000, og her skulle de alvorligt skadede samles til behandling. ${ }^{36}$

"Jeg kan ikke glemme det uhyggelige syn, som mødte mig ombord på damperen, hvor såvel gulvet og bænkene i salonen var optaget af sårede. Major Schack lå ved siden af mig. Han havde fået en kugle i brystet. På den anden side af mig lå en blodig mand med skadet næse og lårben. Manden blev efter nogen tids forløb så rask, at han kunne besøge mig under min sygdom. Han sagde, at han havde været forstærkningsmand og kusk hos en godsejer «. ${ }^{37}$

Det viste sig, at af de to finske sårede havde Carlsson forholdsvis lette skader, og han kunne vende tilbage til sin enhed i juni. Det var værre med Liikanen. Han blev først behandlet i Artilleriskolens lokaler på Christianshavn. Han var allerede i bedring og havde fået orlov fra militærtjenesten, da der gik betændelse i benet. Diagnosen lød ifølge Åbo Underrättelser: "Liikanens i almindelighed spinkle legemsbygning og urolige, sensible sindelag«. Lægerne behandlede ham med kloroform og lapis og kunne ikke garantere for, at han ville klare krisen. ${ }^{38}$ Liikanen lå faktisk for døden, før han lidt efter lidt blev 


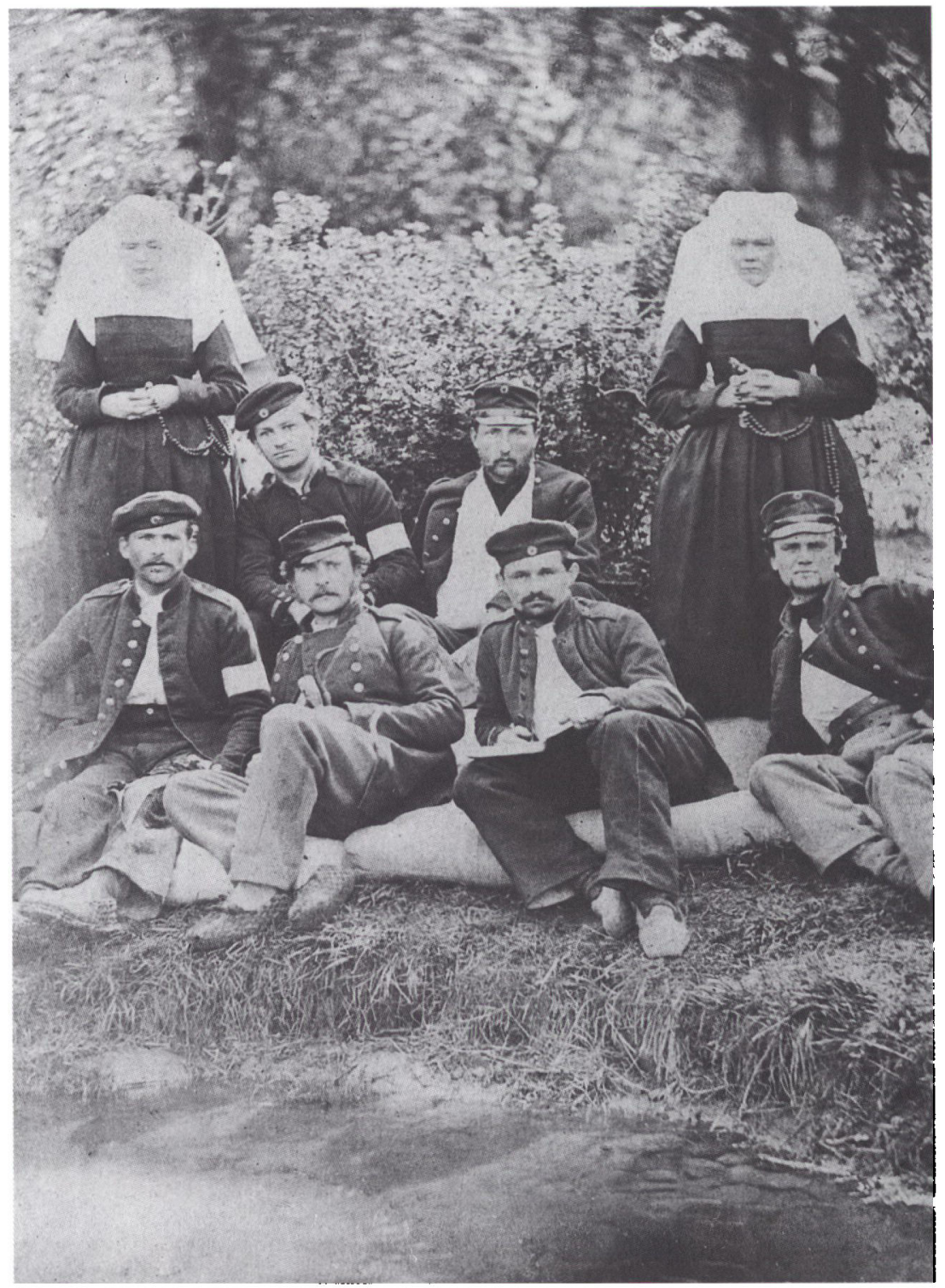

Soldater på lazaret efter slagene i 1864. Foto $i$ Dansk Centralbibliotek for Sydslesvig. 
fra danskerne, indtil Bismarck meddelte, at de skulle anses for normale krigsfanger. ${ }^{40}$

Sanmark var $\mathbf{i}$ fangelejrens annaler indført som finne fra »Helsingfors, Finnland «. I et brev til sine forældre af den 25 . april 1864 fortalte Sanmark, at han umiddelbart efter tilfangetagelsen var blevet forulempet af preussiske soldater. Han havde dog protesteret hos en preussisk officer, som hurtigt havde fået gjort en ende på soldaternes dårlige opførsel. Ellers blev fangerne under turen fra Dybbøl over Flensborg, Hamburg og Berlin til Graudentz behandlet meget godt. I Flensborg forsynede de dansksindede indbyggere fangerne med skjorter, strømper osv. »I Berlin var vi genstand for stor opmærksomhed fra de preussiske gardeofficerer, som formeligen overøste os med komplimenter «. Undtagelsen var Altona, "hvor pøbelen hånede os «. ${ }^{41}$

Graudentz var en gammeldags fæstning ved floden Weichsel. Mandskabet blev indlogeret i 12 hytter (ca. 30 i hver), mens officererne delte et par små værelser. De menige udførte reparationsarbejder i fortet eller arbejdede på de nærliggende marker og høenge. Forholdet mellem officererne var godt, behandlingen fair og bevogtningen let. Fangerne kunne være flygtet, men gjorde det ikke trods alle fristelser, fordi de havde givet deres æresord. Ifølge Sanmark var det største problem ensformigheden, som man forsøgte at overvinde med at promenere, nyde naturen, spille kort og slå kegler. De danske konsuler i Leipzig og Danzig holdt regelmæssigt kontakt med fangerne. I september 1864 blev Sanmark fri. ${ }^{42}$

\section{Epilog}

Våbenhvilen mellem Kongeriget Danmark og de tyske allierede Preussen og Østrig trådte i kraft den 20. juli, mens fredsforhandlingerne i Wien blev afsluttet den 30 . oktober. Fredstraktaten blev godkendt af Folketinget den 9. november og underskrevet af kong Christian IX den 12. november 1864. Krigen kostede Danmark hertugdømmerne Slesvig, Holsten og Lauenburg. Landet blev forvandlet fra en helstat til en nationalstat.

Umiddelbart efter våbenhvilens ikrafttræden indledtes demobiliseringen af den danske hær og hjemsendelsen af soldaterne, også af de frivillige. En efter en forlod også finnerne Danmark. Menige og underofficerer forlod tjenesten mellem 22. august og 27. september. Nogle af dem vendte aldrig tilbage til Finland. Dahlroos, Elenius og 
Saxberg blev vistnok i Sverige, men deres videre skæbne er ukendt. Forssell derimod blev i Stockholm, hvor han ernærede sig som bogholder og desuden stiftede familie. Han døde juleaften 1876. Boxberg vendte tilbage til Helsingfors, hvor han grundlagde en privat handelsskole. Roos slog sig ned som bogholder i Åbo, mens Söderlund fik arbejde som arbejdsleder $\mathrm{i}$ Viborg landkommune. ${ }^{43}$

Vi ved mere om officererne: K. O. Carlsson modtog den 1. september fra det danske krigsministerium en skrivelse, som indeholdt hans afskedigelse og en tak for god og trofast tjeneste. Carlsson havde i den sidste tid gjort tjeneste på Fyns vestkyst. Han forlod Danmark og blev derefter en tid i Stockholm, inden hans skæbne førte ham til Uleåborg, hvor han blev valgt til rådmand. På det tidspunkt befandt Estlander sig allerede i den svenske hovedstad, hvortil også Sanmark tog sig efter at have forladt fangelejren i begyndelsen af september. Det fremgår nemlig af et brev fra Estlander til Liikanen, dateret den 12. september, at de var i Stockholm alle tre lige netop den dag, han selv rejste over til Finland. Sanmark fulgte snart efter.

For Estlander blev eventyret en skuffelse; han fik ingen Dannebrogsorden eller noget spændende at fortælle sine børnebørn. Derimod fik Sanmark den 6. oktober ridderkorset af Dannebrogs tredje klasse. Han genoptog sit gamle erhverv som skovrider, mens Estlander begyndte at arbejde på Föreningsbanken. De talte nødig om krigen. Minderne var ikke udelt positive. Den ene havde været krigsfange, den anden havde ikke fået ilddåben, hvilket onde tunger talte om. Tiden lægede dog sårene, og Estlander blev f.eks. af sine kollegaer kærligt kaldt "Majoren«. Ro og fred prægede resten af disse frivilliges liv. ${ }^{44}$

Den, der kom til at stå som symbolet for de finske frivillige, var Liikanen. Hans skade holdt ham tilbage i København indtil maj 1865. I denne tid kom han sammen med danske politikere og kunstnere. Også det officielle Danmark huskede ham; den 18. maj 1864 blev han forfremmet til sekondløjtnant og den 11. november udnævnt til ridder af Dannebrogsordenen. Som invalid fik han desuden bevilget den s.k. Hædersgave, den danske stats pension for livstid. Den 18. maj 1865 fik han sit afskedsbrev fra krigsministeriet og den 26. skete afrejsen. Den 5. juni 1865 ankom han med skibet »Grefve Berg« til Åbo. Liikanen fik ansættelse som kæmner i Hypotekbanken, hvor han arbejdede resten af sit liv. Hans interesse for de nationale forhold formindskedes ikke med årene, tværtimod blev han engageret $\mathrm{i}$ den finsk-nationale bevægelse i sit hjemland. I 1914 - da Danmark fejrede 50-året for 
krigen i 1864 - blev Liikanen inviteret til København, hvor han fik lejlighed til at hilse på kongen. Inden sin død fik han endnu som et slutfacit på sit ideologiske hverv lov til at opleve Finlands selvstændighed 1917 og genforeningen af Slesvig 1920. Da Herman Liikanen døde i 1926, var bl.a. den danske, ungarske og italienske ambassade i Finland repræsenteret ved begravelsen for at hædre mindet om nationalisten og internationalisten, den sidste finske frivillige. ${ }^{45}$

Hvordan var så de elleve finske frivilliges indsats $\mathrm{i}$ den dansk-tyske krig? For nogles vedkommende forblev indsatsen anonym, mens andre bedre kunne hævde sig. Vitterlig behøvede ingen skamme sig over sin indsats. Men de var trods alt kun elleve i en hær på titusinder! Militær-strategisk måtte indsatsen blive begrænset, hvor godt de end gjorde deres pligt, hvor meget blod de end udgød, hvor svære strabadser de end udstod og hvor mange tapperhedsmedaljer de end fortjente.

Men krig kan være mere end blot koldt stål. Den handler om symboler, værdsættelse, loyalitet, erfaringer. De finske frivillige tog med sig hjem billeder af et Danmark i krig, af danske soldater, der tappert udholdt miseren i forsvaret af deres fædreland - men også af hverdagslivet, især folket i Danmark. Disse billeder blev formidlet gennem de finske aviser videre til et bredere publikum i Finland. Mindet om de nordiske frivillige blev officielt manifesteret ved rejsningen af mindesmærket ved Kastellet i København og obelisken nede ved Dybbøl Banke. Men det levede også videre i menneskenes hukommelse. Da godt og vel 1.000 danskere drog til Finland for at bistå finnerne i vinterkrigen 1939-40, havde mange på deres læber: "Vi husker 1864 «.

NOTER

1. Estlander, B.: Finländska frivillige i danska kriget 1864, Helsingfors 1926 s. 79 .

2. For den historiske baggrund, se f.eks. Christiansen, John \& Stevnsborg, Henrik; 1864 - fra helstat til national- stat, Kabenhavn 1998; Klinge, Matti: Finlands historia 3, Helsingfors 1996. I 1860 'erne bestod forsvaret i Finland af 10.000 russiske og 3500 finske soldater. Værnepligt indførtes først 1881.

3. Helsingfors Dagblad 19.2.1864 (Avi- 
sen skrev flere analyser om Danmark i labet af 1864), se tillige f.eks. Åbo Underrättelser 10.5.1864.

4. Klinge, Matti: Krig, konst och kvinnor, Helsingfors 1997 s. 24ff; Paavolainen, Jaakko: "First-generation Finnish-Americans Serve the United States «, Old Friends-Strong Ties, Niitemaa, Vilho i.a. (ed) Vaasa 1976 s. 235.

5. Den dansk-tydske Krig 1864 I del. Udgivet af generalstaben $1890, \mathrm{Kbhv}$ 1890 s. 159.

6. "... Adjudant ved Skarpskytterne, fabrikant A. W. Møller, "de svenske frivilliges factorum «, som bor i værelset ved siden af mit og som har været mig og de andre finner til stort gavn «. - Rudolf Estlander i Estlander 1926 s. 96.

7. Hanson, H. A.: For Nordens Frihed, 1919 s. 20. Åbo Underrättelser 10.5.1864; Fædrelandet 1.4.1864 - Angående honorærkonsulerne, se Unio Sarlin: Corps consulaire en Finlande I 1719-1917, Turku 1972.

8. Der meldte sig desuden 2 briter og 1 schweizer (1864 - et hundredaarsminde. Red. M. Friis-Møller\&Ernst Mentze. Kobenhavn 1963 s. 264). I Den dansk-tydske Krig 1864 II del. Udgivet af generalstaben 1891, omtales Sanmark og Carisson som svenskere, s. 398 , bilag s. 110 .

9. Muller, C.H: Svenska frivilliga i dansk-tyska kriget 1864. Nordisk krigshistorisk studiefärd 1963.

10. Estlander 1926 passim.

11. Generalguvernøren rejste tiltale mod redaktøren af Åbo Underrättelser, J. V. Lilja, for en artikel 2.1.1864 om situationen i Polen. Generalguvernorens arkiv 1855-1890 (RA 313, Nro 49) ss. 188-189. Riksarkivet, Helsingfors.

12. Personalia over de ovrige frivillige d.v.s. ud over Liikanen: Rudolf Josef Estlander: født 1838 i Lappfjärd i Österbotten, hvor faderen J. J. Estlander var sognepræest. Rudolf tog studentereksamen 1857 og flyttede efter forældrenes død til Helsingfors. Studierne smagte ikke, og i februar 1864 rejste Estlander til Danmark for at deltage i den dansk-tyske krig. Han blev hjemsendt samme efterår som sekondløjtnant. Han fuldførte aldrig sine studier, men fik ansættelse som kasserer på Föreningsbankens hovedkontor i Helsingfors. Han døde 1880 af hjerteslag, 42 år gammel. Anton Sanmiark, født 1829, var søn af kæmneren Carl Anton S. ved poststyrelsen i Helsingfors. Hans mor var født Nykopp. Han gennemgik kadetuddannelsen i Fredrikshamn og giorde nogle år tjeneste ved den finske sapørbataljon, en russisk enhed i Helsingfors. I 1861 fik han efter egen begæring afsked med løjtnantgrad for at indlede en karriere inden for forstvæsenet, d.v.s. han blev inspekter for statsskovhugsten i Kuortane. Den dansktyske krig forte ham ud i felten med kampene ved Dybbøl og fangenskabet $i$ Graudenz som erfaringer. Efter hjemkomsten genoptog han sit erhverv som skovrider i Enare og senere Ruovesi, hvor han giftede sig. Han dode 1897. Knut Oskar Carlsson var født 1835 i Kumo. Han var søn af jagtfoged og klapperfører Otto Bernhard C. Han havde gjort tjeneste som fænrik ved Åbo inddelte skarpskyttebataljon, hvorfra han fik sin afsked. Han havde også provet sig frem i skuespillerfaget. Efter krigen 1864 slog han sig ned i Uleåborg, hvor han blev rådmand. Han døde ugift 1906. Erik Henrik Dahlroos var født $1834 \mathrm{i}$ en husmandsfamilie i Vittis bofjärd. Han havde giort tieneste som ældre underofficer $i$ Åbo bataljon og fik sergentgraden i den dansk-tyske krig. Efter 1864 vendte han ikke tilbage til Finland, men blev formodentlig i Sverige. Hans videre skæbne er ukendt. Jakob Mauritz Elenius (f. 1834) var søn af Erik Elenius, kantor og klokker i Maxmo. Han havde været yngre underofficer i 2. Vasa bataljon. I den danske krig havde han korporalsgrad. Han vendte ikke tilbage til Finland. Vi kender ikke hans senere skæbne. Herman Johan Vilhelm Boxberg, fodt $1835 \mathrm{i}$ Helsingfors, var søn af Herman B., fhv. kvartermester i 2 . finske søekvipage. Han var student, da han tog med til den dansk-tyske krig. Efter hjemkomsten til Finland blev han lærer ved Privata handelsskolan i Helsingfors, hvor han også døde 
1887. Boxberg var gift. Johan Henrik Forssell, blev født $1840 \mathrm{i}$ en købmandsfamilie i Helsingfors. For den danske krig var han grundejer. Efter krigen bosatte han sig i Sverige, hvor han ernærede sig selv og sin familie som bogholder. Han dode 1876 i Stockholm. Johan Mikael Roos var født 1842 i Luvia, faderen var klokker. Han arbejdede som kommis og handelsrejsende. Efter krigen var han ansat som bogholder i Åbo. Han var ugift ved sin derd 1877. Fredrik Saxberg, f. 1843, var søn af en husmand i Vittisbofjärd. Han ernærede sig som kommis og handelsrejsende. Hans skæbne efter den danske krig er ukendt. Han vendte dog ikke tilbage til Finland, men blev sandsynligvis i Sverige. Johan Robert Söderlund, var født 1841 i Åbo, faderen Anders S. var somand. Johan Robert var maskinist. Efter krigen vendte han tilbage til Finland, hvor han fungerede som arbejdsleder. Han var gift. Han gik bort 1910 i Viborg landkommune. - Estlander 1926 passim. - Backström 1993 s $154 \mathrm{ff}$.

13. Mattila, Jukka I: "Herman Liikanen Italiaa yhdistämässä ja Tanskaa puolustamassa (Herman Liikanen - enar Italien och försvarar Danmark), Suomen sotilas Nr. 2 1998, s. 22-23.

14. "Anton Sanmarks brevsamlingar«, citat i Estlander 1926 s. 100.

15. Ibid.

16. R. Estlanders brev til broderen C. G. Estlander af den 10.4.1864, citat i Estlander 1926, s. 91.

17. ÅU 13.3., 31.3.1864, Estlander $1926 \mathrm{~s}$. 92ff, Möller, A. W.: Berättelser från 1864 års danska krig samt om däri deltagande svenska, norska och finska frivilliga, Jönköping 1865 s. 137; 1864 - et hundred aarsminde. Red. M. Friis Möller \& Ernst Mentze. Martins forlag, Kbhv. 1963, s. 269-270.

18. $\AA \mathrm{U}$ 26.4., 10.5.1864; Fædrelandet 12.4.1864.

19. R. Estlanders brev til sin bror C. G. Estlander 10.4. og 11.5.1864; A. Sanmarks brev til broderen C. G. Sanmark 30.3.1864 og til svogeren A. A. Thesleff 18.4.1864, citeret i Estlander 1926 s. $95 \mathrm{ff}$.
20. "Sanmarks brev til Thesleff 18.4.1864", citat i Estlander 1926 ss. 103-104.

21. Sanmarks brev til Helsingfors Dagblad 12.4.1864, publiceret 1.5.1864.

22. "Rolig og uforfærdet passede han sin tjeneste $i$ tur med regimentets andre løjtnanter og ligesom han stedse nod kammeraternes sympati, forstod han også at vinde mandskabets hengivenhed og sætte sig i respekt hos dem, han var sat at kommandere over", skrev en dansk kollega, kaptajn H.A. Hanson langt senere om Carlsson. Hanson 1919 s. 23.

23. Premierløjtnant Gandils rapport 8.5.1864. Forsvarets arkiver, 1864 Dybbøl. Rigsarkivet. - I ovennævinte brev til Thesleff 18.4.1864 indrommede Sanmark visse sprogproblemer, Estlander 1926 s. 103.

24. Brev fra Herman Liikanen 23.4.1864, gengivet af Helsingfors Dagblad 1.5.1864.

25. Sanmarks brev til Helsingfors Dagblad 12.4.1864, publiceret 1.5.1864.

26. K. O. Carlssons brev blev gengivet i Helsingfors Dagblad 3.5.1864.

27. Oberstløjtnant Falkenskjolds rapport 27.10.1864, Forsvarets arkiver, 1864 Dybbøl, Rigsarkivet; Hanson 1919 s. 25.

28. Sanmarks brev til forældrene 25.4.1864, gengivet i Helsingfors Dagblad 18.5.1864.

29. Liikanens brevkoncept til E. Linder 23.4.1864, Herman Liikanens arkiv, Riksarkivet, Helsingfors. - Brevet publiceret $\mathrm{i}$ bearbejdet version $\mathrm{i} \mathrm{Hel}-$ singfors Dagblad 1.5.1864. »Dybböl rapport af kapten Moltke «, Forsvarets arkiver 1864, Rigsarkivet.

30. ÅU 10.5.1864.

31. "Stambog for kapt. Aaroes Korps", Forsvarets arkiver 1864, Rigsarkivet om strejfkorpset f.eks. Hanson 1919 s. $25 \mathrm{ff}$.

32. Muller $1963 \mathrm{~s}$.

33. "Aarres Strejfkorps' arkiv«, Forsvarets arkiver 1864, Rigsarkivet.

34. ÅU 23.7.1864, Christensen \& Stevnsborg $1998 \mathrm{~s}$. $107 \mathrm{ff}$.

35. Sanmarks brev til forældrene 25.4.1864, Helsingfors Dagblad 18.5.1864. 
36. Liikanens beretning, publiceret i Helsingfors Dagblad 1.5.1864. Se også Christensen \& Stevnsborg 1998 s. $107 \mathrm{ff}$.

37. Liikanens erindringer 50 år efter krigen, gengivet i Dagbladet 16.4.1914.

38. ÂU 5.7.1864.

39. Liikanens dagbog 7.7.1864, Herman Liikanens arkiv, Riksarkivet, Helsingfors - De sk. sygevogtere omtales i Christensen \& Stevnsborg 1998 s. 106.

40. Muller 1963 s. 5.

41. Sanmarks ovennævnte brev 25.4.1864, Helsingfors 18.5.1864.

42. Beretning om besag hos danske fan- ger i tyske fæstninger 10.9.1864; feltpræst Ludvig Wagner, "Krigsfanger Graundentz «. Forsvarets arkiver 1864, Rigsarkivet. - Sanmarks brev 25.4.1864, Helsingfors Dagblad 18.5.1864.

43. Söderlund blev bevilget afsked 31.7. men hjemsendt 22.8., Roos og Saxberg en dag senere, Boxberg 26.8., Dahlroos og Elenius 31.8. samt Forssell 27.9. Müller 1865 s. 137. Backström 1993, s. 154-156.

44. Hansson 1919 s. 24 . Estlander 1926 passim.

45. Estlander 1926 s. $115 \mathrm{ff}$. 